\title{
Proximate composition, phytochemical screening and antioxidant activity of ten selected wild edible Nigerian mushrooms
}

\author{
Egwim EC ${ }^{* 1}$ Elem $\mathrm{RC}^{1}$, and Egwuche $\mathrm{RU}^{2}$ \\ * Corresponding Author: TEL.: 07065809474, Email: evanschidi@gmail.com \\ ${ }^{1}$ Department of Biochemistry, Federal University of Technology, P.M. B 65, \\ Minna, Niger State, Nigeria. \\ ${ }^{2}$ Department of Biochemistry, IBB University, Lapai, Niger State, Nigeria.
}

\begin{abstract}
Wild edible mushrooms of several species are grown in different part of Nigeria for various reasons. In this study, the proximate, antioxidant activity as well as the phytochemical screening of ten selected wild edible Nigerian mushrooms including Cantharelle cibarius, Laccaria amethysta, Clitocybe odora, Lepista nuda, Macrolepiotata procera, Lepista saeva, Lactarius deliciousus, Laccaria laccata, Pleurotus ostreatus and Hericium erinaceus were investigated. The mushrooms were harvested fresh, sun dried, pulverized and analyzed according to standard procedures. Proximate analysis showed high level of proteins $(14.03-60.38 \%)$, crude fibre(3.94 - 20.36\%), carbohydrate(4.17 -32.50\%), ash (17.44 - 33.60\%), fat(1.29-14.29\%) and folic acids $(4.75-5.51 \mathrm{~g} / \mathrm{g})$ in all species. Mineral analysis of all species indicated the presence of potassium, sodium, magnesium, manganese, calcium, copper and Iron. Potassium is of the highest amount in all species of plant $(1370-5710 \mathrm{~g} / 100 \mathrm{~g})$. High antioxidant activity was also observed in these mushrooms with the specie $L$. amethysta and $L$. nuda exhibiting the strongest antioxidant activity with values as high as 53.64 and $53.65 \mathrm{~nm}$ respectively. Phytochemical screening revealed the presence of varying quantities of alkaloids, flavonoids, saponins, tannins with absence of anthraquinones and steroids. These bioactive compounds together with the high antioxidant activities obtained in some species and the nutrient contents in all species may be responsible for their nutritional and therapeutic uses. These results therefore not only make these wild edible mushrooms popular to consume as good food sources but may also be valuable in drug development.
\end{abstract}

Keywords: Wild mushrooms, phytochemicals, proximate composition, Antioxidant activity.

\section{INTRODUCTION}

Mushrooms have continued to generate a lot of interest particularly in its consumption as food [1], in the cure of diseases [2], in bioremediation and as important items of commerce in Nigeria [2] and all over the world. The increased interest in consumption of mushrooms as food stems from their nutritional, antioxidant and therapeutic values. Studies have shown that tropical mushrooms are highly rich in proteins, minerals, vitamins, crude fiber and carbohydrate with low fat and oil content. The protein content of mushrooms has been reported to be twice that of vegetables and four times that of oranges and significantly higher than that of wheat $[3,4,5]$. The high level of vitamins in mushrooms particurlary vitamin $C$ and $D$ has been reported as responsible for its antioxidative activity [5, 6]. Mushrooms contains also an appreciable quantities of crude fibres, although, little information exist on Total Dietary Fibre
(TDF) content of mushrooms. The crude fibre content values reported from many studies suggest that mushrooms are potential sources of dietary fibre [7, 8]. Mushrooms generally contain low fat and oil content $[5,9]$. Because of the low fat and oil content, they are recommended as good source of food supplement for patients with cardiac problems or at risk with lipid induced disorders.

Despite the many studies on nutrients and minerals contents of different mushroom species globally, little or no work has been carried out on the antioxidant activity in wild edible species in parts of Nigeria. Also there are several wild edible species of mushrooms which are yet to be exploited and it is to this end that the present work is aimed at investigating the proximate composition, antixioxidant and the phytochemical content of ten selected wild edible Nigerian mushrooms. 


\section{MATERIALS AND METHODS}

Sample collection and preparation:The mushrooms used for this study were collected from logs of wood, palm logs and humus soil from different location at the base of a thick forest located at the mountain Ugu-Uleri in Biledeba Ntezi, Ishielu Local Government Area of Ebonyi State Nigeria and identified by a taxonomist, Professor Onyekwere S.S.C of Applied Biology Department, Ebonyi State University Abakaliki, Nigeria.

The mushrooms were uprooted, destalked, washed and sun-dried by constant exposure to sunlight for 2 -4 days while turning the mushrooms to avoid fungal growth. The mushrooms were later milled to obtain mushroom meals (MRMS) using mortar and pestle and this was stored in a container until needed for analysis.

Proximate Analysis: Proximate compositions of the mushroom flour were determined by the Official Methods of the Association of Official Analytical Chemists [10, 11]. Ash, crude fibre, total carbohydrates and crude protein were determined by dehydration, Weende [11], DNS colorimetric and Kjeldahl $(\mathrm{N} \times 6.25)$ methods, respectively [8]. All the calculations were carried out on dry weight basis of the mushrooms. Mineral elements in the dry samples were determined by the wet digestion extraction methods by Association of Official Analytical Chemists[11] and folic acid content was also determined using the spectrometric method $[12,13)$.

Antioxidant Activity determination: This was carried out using lipid peroxidation method in tissue homogenate. A weighed liver sample of $0.5 \mathrm{~g}$ was homogenized in $19.5 \mathrm{ml}$ of potassium chloride solution, and the homogenate was stored at a temp of $0-4^{0} \mathrm{C}$. To a first centrifuge tube, $2.0 \mathrm{ml}$ of the homogenate was added to $0.2 \mathrm{ml}$ of distilled water and $2.0 \mathrm{ml}$ of homogenate, $0.1 \mathrm{ml}$ of ascorbic acid solution and $0.1 \mathrm{ml}$ of mohr salt solution into second centrifuge tube; to the third centrifuge tube, same components as have been added to the second tube was added in addition to $1 \mathrm{ml}$ of trichloroacetic acid solution. The three centrifuge tubes were placed in a water bath at $37^{\circ} \mathrm{C}$ for 10 minutes and $1 \mathrm{ml}$ of trichloroacetic acid solution was added to the first and second tube. It was then centrifuged for 10 minutes at 3000rpm. Two $\mathrm{ml}$ of supernatant was poured into three clean test tubes and $1 \mathrm{ml}$ of thiobarbituric acid was added and placed in a boiling water bath for 10 minutes and was allowed to cool in ice to room temperature. The absorbance of the supernatant was then read at $532 \mathrm{~nm}$ for the ten samples [14]

Phytochemical Screening: The following phytochemicals were screened according to standard methods [15, 16 and 17]; anthraquinones, flavonoids, alkaloids, steroids, tannins, fatty acid and saponins.

\section{RESULTS}

Proximate composition: Proximate composition of the ten selected wild edible Nigeria mushrooms showed the presence of high quantities of total ash (17.4 - 33.60\%), crude fibre (3.94 - 20.36\%), carbohydrate(4.17-32.50\%), protein (14.03\% $60.38 \%)$ and low fat(1.29-14.29\%) content in the various species (Table 1 ).

The ten species of mushrooms were also found to contain variable amounts of minerals such as potassium, sodium, copper, magnesium, manganese, copper and calcium with potassium being the most abundant mineral in the mushrooms (Table2).

Table 3 shows the result of folic acid compositions. The highest level of folic acid was found in the species $H$. erinaceosus $(5.51 \mathrm{~g} / \mathrm{g})$ while the species $M$. procera had the lowest amount $(4.72 \mathrm{~g} / \mathrm{g})$. 
Table 1: Proximate Composition of 10 Selected Wild Edible Nigeria Mushroom Species.

\begin{tabular}{|c|c|c|c|c|c|c|}
\hline $\mathrm{S} / \mathrm{N}$ & Species & Ash \% & Fat $\%$ & Crude Fibre $\%$ & Crude Protein\% & Carbohydrate \% \\
\hline 1 & $\begin{array}{r}\text { Cantharelle } \\
\text { cibarius }\end{array}$ & $25.78 \pm 4.28$ & $9.14 \pm 0.84$ & $13.64 \pm 0.59$ & $26.25 \pm 1.93$ & $18.00 \pm 0.44$ \\
\hline 2 & $\begin{array}{l}\text { Laccaria } \\
\quad \text { amethysta }\end{array}$ & $32.37 \pm 5.67$ & $8.95 \pm 0.35$ & $15.72 \pm 0.23$ & $32.38 \pm 0.22$ & $8.20 \pm 0.39$ \\
\hline 3 & Clitocybe odora & $17.44 \pm 0.41$ & $14.29 \pm 0.24$ & $12.72 \pm 0.77$ & $41.13 \pm 0.20$ & $11.50 \pm 0.21$ \\
\hline 4 & Lepista nuda & $20.56 \pm 0.002$ & $9.33 \pm 1.28$ & $3.94+0.24$ & $60.38+0.20$ & $4.17+0.53$ \\
\hline 5 & $\begin{array}{c}\text { Macrolepiotata } \\
\text { procera }\end{array}$ & $33.11 \pm 4.10$ & $5.24 \pm 0.54$ & $11.54 \pm 0.54$ & $35.88 \pm 0.62$ & $8.00 \pm 0.24$ \\
\hline 6 & Lepista saeva & $32.44 \pm 0.013$ & $5.43 \pm 0.17$ & $10.92 \pm 0.39$ & $29.75 \pm 0.91$ & $11.50 \pm 0.21$ \\
\hline 7 & $\begin{array}{l}\text { Lactarius } \\
\quad \text { deliciousus }\end{array}$ & $32.67 \pm 0.16$ & $4.94 \pm 0.46$ & $11.45 \pm 0.17$ & $35.00 \pm 0.45$ & $11.60 \pm 0.24$ \\
\hline 8 & Laccaria laccata & $33.60 \pm 0.36$ & $8.48 \pm 0.08$ & $10.96 \pm 0.52$ & $14.03 \pm 0.01$ & $8.17 \pm 0.37$ \\
\hline 9 & $\begin{array}{l}\begin{array}{c}\text { Pleurotus } \\
\text { ostreatus }\end{array} \\
\end{array}$ & $20.55 \pm 0.13$ & $4.89 \pm 0.13$ & $20.36 \pm 0.25$ & $27.13 \pm 0.38$ & $32.50 \pm 0.12$ \\
\hline 10 & $\begin{array}{l}\text { Hericium } \\
\quad \text { erinaceus }\end{array}$ & $\begin{array}{l}20.55 \pm 0.13 \\
32.89 \pm 0.093\end{array}$ & $1.29 \pm 1.20$ & $16.76 \pm 0.21$ & $41.13 \pm 0.58$ & $15.00 \pm 0.18$ \\
\hline
\end{tabular}

Table 3: Folic Acid Composition of 10 Selected Edible Wild Nigeria Mushroom.

\begin{tabular}{|c|c|c|}
\hline S/No & Sample & $\begin{array}{c}\text { Folic acid } \\
\text { content }(\mathrm{g} / 100 \mathrm{~g})\end{array}$ \\
\hline & Blank/Standard & $5.06 \pm 0.20$ \\
\hline 1. & C. cibarius & $5.07 \pm 0.39$ \\
\hline 2. & L. amethysta & $5.30 \pm 0.38$ \\
\hline 3. & C. odora & $4.79 \pm 0.42$ \\
\hline 4. & L. nuda & $5.02 \pm 0.40$ \\
\hline 5. & M. procera & $4.72 \pm 0.42$ \\
\hline 6. & L. saeva & $5.17 \pm 0.39$ \\
\hline 7. & L. deliciousus & $4.93 \pm 0.41$ \\
\hline 8. & L. laccata & $4.87 \pm 0.41$ \\
\hline 9. & P. ostreatus & $4.75 \pm 0.42$ \\
\hline 10. & H. erinaceosus & $5.51 \pm 0.36$ \\
\hline
\end{tabular}

Antioxidant Activity : Antioxidant activity of the ten selected wild edible Nigerian mushrooms is shown in Table 4. Amongst all species studied, L. amethysta and L. nuda exhibited the strongest antioxidant activity with values ranging from 53.64 to $3.65 \mathrm{nM}$.
Phytochemical Screening: Phytochemical screening (Table 5) indicates the presence of saponins, flavonoids, tannins, and alkaloids while anthraquinones and steroids were not detected in all species of wild edible Nigeria mushrooms studied

Table 4. Antioxidant Activity of 10 Selected Wild Edible Nigerian Mushrooms

\begin{tabular}{|c|c|c|}
\hline S/No & Species & $\begin{array}{l}\text { Antioxidant } \\
\text { Activity (nM) }\end{array}$ \\
\hline & Control & \multirow{11}{*}{$\begin{array}{l}46.38 \pm 6.09 \\
49.74 \pm 6.95 \\
53.64 \pm 8.00 \\
52.10 \pm 8.22 \\
53.65 \pm 8.00 \\
38.75 \pm 8.20 \\
34.46 \pm 5.36 \\
34.46 \pm 5.36 \\
34.77 \pm 5.77 \\
45.84 \pm 7.43 \\
36.31 \pm 5.05\end{array}$} \\
\hline 1. & C. Cibarius & \\
\hline 2. & L. amethysta & \\
\hline 3. & C. odora & \\
\hline 4. & L. nuda & \\
\hline 5. & M. procera & \\
\hline 6. & L. saeva & \\
\hline 7. & L. delicrousus & \\
\hline 8. & L. laccata & \\
\hline 9. & P. ostreatus & \\
\hline 10. & H. erinaceosus & \\
\hline
\end{tabular}


Table 5: Phytochemical Screening of Ten Selected Wild Edible Nigeria Mushroom

\begin{tabular}{|l|c|c|c|c|c|c|c|c|}
\hline S/No & Anthraquinones & Flavonoids & Alkaloids & $\begin{array}{r}\text { Fehling } \\
\text { te } \\
\text { st }\end{array}$ & $\begin{array}{r}\text { Steroids } \\
\text { Tannins }\end{array}$ & Saponins & High fatty acids \\
\hline 1. & --- & +-- & +++ & ++- & --- & +-- & +-- & ++- \\
\hline 2. & --- & ++- & +++ & ++- & --- & ++- & ++- & ++- \\
\hline 3. & --- & +++ & +++ & +++ & --- & ++- & ++- & +-- \\
\hline 4. & --- & +++ & +++ & +++ & --- & ++- & +++ & ++- \\
\hline 5. & --- & +++ & +++ & +++ & --- & ++- & --- & ++- \\
\hline 6. & --- & +++ & +++ & +++ & --- & ++- & +-- & ++- \\
\hline 7. & --- & +++ & +++ & +++ & --- & +-- & ++- & ++- \\
\hline 8. & --- & +++ & +++ & +++ & --- & +-- & +-- & +-- \\
\hline 9. & --- & +++ & +++ & +++ & --- & ++- & ++- & +-- \\
\hline 10. & --- & +++ & +++ & +++ & --- & +-- & +-- & +-- \\
\hline
\end{tabular}

\section{DISCUSSION}

The results obtained from the proximate analysis of all ten species of wild edible Nigerian mushrooms showed that they are good sources of nutrients such as protein, dietary fibre and therefore can be ranked as protein rich food due to their relatively high protein content in the range of $14.03 \%$ in Pleurotus ostreatus spp to $60.38 \%$ in Mcrolepiotata procera spp. The most distinguishing feature of this analysis is the very high protein content $(60.38 \%)$ in Mcrolepiotata procera spp. This value is higher than the values reported in previous studies on mushrooms $[18,19,20]$. It is also higher than those reported for some protein- rich foods such as green vegetables [21], cowpea seeds (22.5\%) and lima beans (23.3\%) [22]. However the protein content of other species which was found to be in the range of $14.03 \%$ $41.13 \%$ is in agreement of results from previous studies $[19,23]$. The studied mushrooms can therefore be ranked as protein rich food for both humans and livestock thus can support the protein need of the poor peasants and solve the problem of malnutrition. Therefore the molecular studies and commercialization of these mushrooms should be encouraged.

Potassium, Iron, calcium and magnesium which are nutritionally important were found in reasonable amount while manganese and sodium were in minimal amount. Their values are comparable with values reported for some other wild edible Nigerian mushrooms [24]. Potassium was found to be the most abundant mineral present in all specie ranging from 1370 - 1761g/100g. The preponderance of potassium in these mushrooms may be due to the absorption and accumulation of this element from their habitat. Minerals generally in the diet are required for metabolic reactions, transmission of nerve impulses, rigid bone formation and regulation of water and salt balance among others.

Detection of Folic acid (vitamin B9) in all species within the range of 4.72 to $5.51 \mathrm{~g} / 100 \mathrm{~g}$ shows that these mushrooms are rich in vitamins B9. Pharmaceutically, folic acid has been implicated in treatment of anaemia in sicklers and pregnant women [25]. This high content of vitamins in mushrooms is in correlation with the findings that mushrooms are rich source of vitamins, proteins and minerals [26, 27]. Thus mushrooms holds tremendous potentials as a source of raw material for drug manufacture [25]

In this Study, inhibition of lipid peroxidation (antioxidant activity) revealed that all ten species of wild Nigerian mushroom have antioxidant activity as they were able to inhibit peroxidation induced in liver homogenate. C. cibarius, L. amethysta, C.odora and L. nuda species elicited 49.74, 53.64, 52.10, 53.64nM antioxidant activity respectively compared to the standard, ascorbic acid $(46.38 \mathrm{nM})$ while the remaining species inhibited peroxidation to a lower extent $(45.4-34.46 \mathrm{nM})$. This result agrees with other findings that show that mushrooms are good source of vitamins and flavonoids and that most wild edible Nigerian mushrooms posses antioxidant activities [28]. Lipids peroxidation has been shown to result from cumulative effect of reactive oxygen species, which disturb the assembly of the membrane causing changes in fluidity and permeability, alterations of ion transport and inhibition of metabolic processes [29]. These mushrooms particularly $C$. cibarius, $L$. amethysta, C.odora and $L$. nuda species therefore can be suggested to act as antioxidant agents. 
Phytochemical screening of these mushrooms revealed the presence of saponins, alkaloids, flavonoids tannins which varies quantitatively from low to highly present. Steroids and anthraquinones were not detected. These results are in correlation with the previous work on mushrooms [30, 31] and other leafy vegetables [32]. Anthraquinone absence however do not agree with previous work on mushrooms phytochemicals[32,33].

It is known that Saponins inhibit $\mathrm{Na}^{+}$efflux by blockage of the influx of concentration in the cells, activating a $\mathrm{Na}^{+}-\mathrm{Ca}^{2+}$ antiporter in cardiac muscles. The increase in $\mathrm{Ca}^{2+}$ influx through this antiporter strengthens the contraction of heart muscles [33].

The valuable pharmaceutical properties of mushroom may also be attributed to the presence of alkaloids which has been reported to have a stimulating effect, act as topical anaesthetic in Ophthalmology, powerful pain reliever, antipuretic action among other uses [34].

High Flavonoids level may help provide protection against oxidative stress induced diseases by contributing along with other antioxidant vitamins, and enzyme to the total ant oxidative defense system of the human body. Many studies have attributed that antioxidant properties are due to the presence of flavonoids [35] hence may be a reason for the high lipid peroxidation inhibition found in certain species of the studied mushrooms.

The medicinal values of mushroom therefore may be attributed to the presence of these phytochemicals.

\section{CONCLUSION}

Based on the result of these findings, it can be concluded that the ten edible wild Nigeria mushrooms investigated can serve as a constituents of human diet supplying the body with proteins, minerals and vitamins thereby could be utilized as a cheap source of protein, energy, minerals and antioxidant supplement for both man and/or livestock.

However, these mushrooms are grown in the wild and therefore for improved utilization, there is need to grow them domestically.

The antioxidant activities of these mushrooms need further investigation as only lipid peroxidation method was use in its estimation and there would be need to establish their effect on the animals.

\section{REFERENCES}

1. Chang ST Mushroom Production in South East Asia, Mushroom. Newsle Tropic, 1980; 4:5-10.

2. Bushwell YA and Chang ST Edible Mushroom Attributes and Applications in Genetics and of Edible Mushrooms. 1993; $297-334$.

3. Aletor VA Anti Nutritional Factors in Some Nigerian Feedstuffs, Herbage by Products, Crops Resources and Browse Plants. A Monograph Prepared For the Presidential Task Force on Alternative Formulation of Live Stock Feed Products Development, Quality, Evaluation and Health Implications. Cabinet Office, Lagos, Nigeria, 1990.

4. Fasidi IO Studies on Volvariella esculenta mass singer, Cultivation on Agricultural Wastes and Proximate Composition of Stored Mushrooms, Food Chemistry, 1996; 55:161 - 163.

5. Okwulehie IC and Odunze ET Evaluation of the Myco-chemical and Mineral Composition of Some Tropical Edible Mushroom. Journal of Sustainable Agriculture and Environment, 2004 6:1; 63-70.

6. Bano ZS and Rajarathnam Studies on the Cultivation of Pleurotus Species. Mushroom J., 1981; 101:243 245.

7. Crisan EV and Samds A Nutritional Value of Edible Mushrooms. In the Biology and Cultivation of Edible Mushrooms, Academic Press, New York 1978; 137167.

8. Kurasawa S L, Sugahana J and Hayashi J Studies on Dietary Fibre of Mushroom and Edible Wild Mushroom and Plants. Nut. Rep. Int.1982; 26:167173.

9. Oso BA Pleurotus Tuber Regium from Nigeria. Mycologia, 1977; 69:271-279.

10. AOAC Official method of Analysis. Association of Official Analytical Chemists. $10^{\text {th }}$ Ed., Washington DC. 1987.

11. AOAC Official Method of Analysis. Association of Official Analytical Chemist. $13^{\text {th }}$ Ed., Washington DC.1989.

12. AOAC Official method of Analysis, Tenth Edition, Washington DC, Association of Official Analytical Chemists. 1980.

13. Mattila $P$, Suonpaaa $K$ and $V$ Piironen Content of vitamins, mineral elements and some phenolic compounds in cultivated mushrooms. Journal of 
Agriculture and Food Chemistry, 2001; 49: 23432348.

14. Stroev EA and Makarova VG Laboratory Manual in Biochemistry. $2^{\text {nd }}$ Edn Mir Publishers Moscow, 1989; 253-254.

15. Sofowora AO Medicinal Plants and Traditional Medicine in Africa. Spectrum Books, Limitedlbadan, Nigeria. 1982; pp 6 and 154

16. Harborne JB Phytochemical Methods. Chapman and Hallimited. London 1973; 11 - 113.

17. Trease GE and MD Evans A text book of Pharmacognosy. 13th Ed. Builler Tindall and Caussel London .1989; pp176-180

18. Aremu MO Basu SK Gyar SD Goyal A Bhowmik PK and Datta Banik $S$ Proximate Composition and Functional Properties of Mushroom Flours from Ganoderma spp., Omphalotus olearius And Hebeloma mesophaeum used in Nasarawa State, Nigeria. Mal J Nutr, 2009; 15(2): 233 - 241,

19. Adejumo, $T \mathrm{O}$ and Awosanya O B Proximate and mineral composition of four edible mushroom species from South Western Nigeria. African Journal of Biotechnology 2005; 4(10):1084-1088.

20. Aletor VA and Aladetimi OO Compositional studies on edible tropical species of mushrooms. Food Chem., 1995; 54(3): 265-268.

21. Jonathan $\mathrm{S}$ Vegetable growth requirements and antimicrobial activities of some higher fungi in Nigeria. Ph.D. thesis, Dept of Botany and microbiology, University of Ibadan. 2002

22. Ghogomu R, and BL Sondengam Laphirones $D$ and E: Two new cleaved bioflavonoids from Lophira lanceolata. J. Nat. Prod. 1989; 52(2):284-288;

23. Degreef J, Malaisse F, Rammeloo J and E Baudart Edible mushrooms of the Zambezian woodland area: A nutritional and ecological approach. Biotechnology, Agronomy, Society and Environment, 1997; 1: 221 231.
24. Aletor VA Compositional Studies on Edible Tropical Specials of Mushrooms. Food Chem., 1995; 54:256 268.

25. Qui $U$ and Lui $Y$ Fruthody Production in Basidiomycetes. Applied Microbiological and Biotech. 2000; 54:141-152.

26. Edeoga $\mathrm{HO}$ and Gomina A Nutritional values of some non-conventional leaf vegetables of Nigeria. Journal of Economic Botany, 2000; 24: 7-12

27. Lattif LA, Daran ABM and MohammedAB Relative Distribution of Minerals in the Pileus and Stalk of Some Selected Edible Mushroom. Food Chemistry, 1996; 56:155-121.

28. Okwukhie IC and Odunze ET Evaluation of the Mycochemical and Mineral Composition of Some Tropical Edible Mushroom. Journal of Sustainable Agriculture and Environment, 2004B; 6:157-162.

29. Nigam $S$ and Schewe $T$ (Phopholipase A2s and lipid peroxidation. Biochim Biophy Acta, 2000. 1488: 167181.

30. Kadiri $\mathrm{M}$ and Fasidi $\mathrm{IO}$ Secondary plant products in some Nigerian mushrooms. Niger J Bot 1992; 5: 187192.

31. Hammond WJ Changes in composition of harvested mushrooms (Agaricus bisporus) Phytochemistry, 1978; 18: 415-418.

32. Akindahunsi AA Phytochemical Screening and Nutrient - Antinutrient Composition of Selected Green Leaf Vegetables. African Journal of Biotechnology, 2005; 4:6

33. Schneider $\mathrm{G}$ and Wolfling J Synthetic cardenolides and related compounds. Current Organic Compounds, 2004; 8:14

34. Edeoga $\mathrm{HO}$ and Enata DO Alkaloids, Tannins and Saponins Content of Some Medicinal Plants. Journal of Medical and Aromatic Plant Science, 2001; 23:344349.

35. Harborne JB and Williams CA Advances in flavonoid research since 1992. Phytochemistry, 2000; 55: 481504. 